\title{
An analysis of psychological endurance and personality traits of individuals doing sports and not doing sports by various variables
}

\author{
Şar Nuriye Şeyma ${ }^{1 A B C D E}$, Soyer Fikret ${ }^{2 A B C D E}$, Koç Mustafa ${ }^{3 A B C D E}$ \\ ${ }^{1}$ High School of Physical Education and Sports, Mustafa Kemal Univercity, Turkey \\ ${ }^{2}$ Physical Education and Sports Science Faculty, Sakarya University, Turkey \\ ${ }^{3}$ Education Faculty, Psychological Counseling and Guidance Service, Sakarya University, Turkey
}

Authors' Contribution: A - Study design; B - Data collection; C - Statistical analysis; D - Manuscript Preparation; E - Funds Collection.

\begin{tabular}{|c|c|}
\hline \multicolumn{2}{|l|}{ Abstract } \\
\hline Purpose: & $\begin{array}{l}\text { The aim was to examine the psychological endurance and personality levels of the students studying at } \\
\text { Faculty of Education and students studying at Faculty of Sports Sciences. }\end{array}$ \\
\hline Material: & $\begin{array}{l}\text { Target population of the study was composed of students studying at Sakarya University in the academic } \\
\text { year 2015-2016. The sample of the research consisted of a total of } 365 \text { ( } n=197 \text { males, } n=168 \text { females) } \\
\text { participants. They were educated at Faculty of Education ( } n=166) \text { and Faculty of Sports Sciences ( } n=199) \text { at } \\
\text { Sakarya University. "Personal Information Form" by the researcher, Turkish adapted version of "Personality } \\
\text { Inventory" were implemented. Also, Turkish adapted version of "Psychological Endurance Scale for Adults" } \\
\text { were implemented. T-test was used for paired comparisons. Pearson Product-Moment Correlation ( } r \text { ) } \\
\text { Coefficient was employed to determine the relationship between psychological endurance and five factor } \\
\text { personality traits of the participants. }\end{array}$ \\
\hline Results: & $\begin{array}{l}\text { There was a significant difference between sporting situations, sporting year, sports branches of students in } \\
\text { terms of total scores of psychological endurances. There was also a significant difference between gender, } \\
\text { sporting situation, sporting year and socio-economic situations in terms of the personality traits of the } \\
\text { students. }\end{array}$ \\
\hline Conclusions & $\begin{array}{l}\text { The results show that the psychological endurance levels of those who do not play sports are lower than } \\
\text { those who do any of the individual sport branches or team sports. In short, it can be said that doing sports } \\
\text { affects psychological endurance positively. }\end{array}$ \\
\hline & 位 \\
\hline
\end{tabular}

\section{Introduction}

In addition to being in good relationships with people to survive, they need to be healthy and fit. They need to have a good mindset and bodily development. The World Health Organization (WHO) thinks that a person can be a healthy individual if biologically, psychologically, and socially efficient. It is not only being healthy with physical competence; it means that the individual must be healthy both psychologically and sociologically. Individuals with healthy biological, physiological and psychological structures have the opportunity to create a positive personality structure. In situations where the conditions are incomplete or inadequate, negative personality structures emerge. It can be said that sports enable the person to develop in sociological, physical and psychological sense and contribute to the personality development. The individual struggling to adapt to the environment faces a number of problems in her/his life. These can be the loss of a loved one, dismission from work, a fatal disease, and the destruction of family integrity. If one does not have strength to protect oneself, one feels weak against problems and experiences psychological depression and physical discomfort. There are also people around, who continue to live their lives even against the greatest disasters they have faced in their lives. They themselves produce the necessary energy and power to bind themselves to life. These individuals

(c) Şar Nuriye Şeyma, Soyer Fikret, Koç Mustafa, 2018 doi:10.15561/20755279.2018.0206 who have succeeded in surviving against the difficulties experienced by their living skills are individuals who are aimed at being healthy. They have individual goals and they aim to live a more meaningful and quality life [1]. Psychological endurance is defined as "having good results despite serious threats to the person's development and cohesion" [2]. Psychological endurance is not a property that remains unchanged from birth to death. The strength of the individual is variable, and the effects of events that he or she has experienced are also important. The person may be durable in one development area but not in another development area [3, 4]. Psychological endurance deals not only with survival, but also with the cognitive, emotional attitudes and behaviors required to enrich life during development. The concept is explained by the existentialist approach. According to the existentialist approach, the individual must have the ability to make decisions, to take initiative. They need it to make life meaningful in the possibilities that exist and continue in life. This approach is to be highly effective in discriminating people. These are who have high level of psychological endurance, who can cope with stress and difficulties, and who struggle with behavioral attitudes that cause disease [5]. There are many personality traits that can be associated with psychological endurance. These; related to psychological endurance, self-esteem, hope, learned optimism, life satisfaction, positive emotionality, optimism. However, psychological endurance does not 
only refer to all or nothing, but also to be unstable [6].

Nowadays, we can define personality as the mental, emotional, and physical reactions that lead to the life of the individual. It is also the whole behavioral patterns that distinguish the individual from others and show a certain consistency, while not having any common personality definition that scientists agree on [7]. The main factors that constitute a person's personality are thought, ability, interest, attitude, behavior and actions. These elements are reflected out by the person's appearance, movements, facial expressions, gestures and harmony with their surroundings. Within the integrity of the personality, each person has his or her own unique features that make it different from other people. These features are linked to some of the major items of personality and are reflections of them. For example; good or bad remembrance, quick emotion, anger, irritability, good speech are different features that distinguish people from each other. Besides these, the dressing style of the person, walking, hand and arm movements, voice tone and likings are part of the personality [8].

When we look at the relationship between personality and sport, sport is a form of behavior that meets basic needs at the same time. Allowing the individual to achieve the goals of the drives that are caused by the biological instincts. Sport is not only a physical activity, but also the process of socialization and fitting in the society. The interaction in the sporting environment, then, provides suitable possibilities for emotional emptying and control. The individual participating in sportive activities has the opportunity to express their feelings through movements. It provides a way to empty emotions characterized as maladaptive behavior, such as aggression, anger, shyness, jealousy, and help them be controlled. Thus, it also has a positive impact on the adaptation process. At the same time, sport has a positive effect on the neurovegetative nervous system, helping it to function in a balanced manner. This helps to overthrow excitement, aggression, and anger. Achievements in sports increase the confidence of individuals in themselves [9].

Two different groups emerged in the study of the relationship between personality and sportive performance. Morgan defines the first group as the adopters who admit the pure idea that the personality has a significant relationship with sporting success. He defines the other group as a skeptical group that advocates the idea that the personality has no effect in sporting success. Neither the pure nor the skeptical opinion turned out to be true. Rather, it can be said that there is a relationship between personality and sporting success. However, this relationship is far from perfect. Even if knowing the personality traits and the special circumstances involved helps to predict sporting behavior and success, this prediction is not certain.

\section{Material and Method}

\section{Participants}

Participants consists of the students of the Faculty of Sports Sciences and the Faculty of Education of Sakarya
University in the academic year 2015-2016. The sample of the research consists of 365 students (n(male)=197, $\mathrm{n}($ female $)=168)$. They were selected by random sampling method among the students of Sakarya University Hendek Education Faculty $(\mathrm{n}=166)$ and Sports Sciences faculty $(n=199)$ students in 2015-2016 academic year. The questionnaire was tried to be applied to the students in the sampling group. The students who were not there and the students who did not want to participate in the questionnaire were not surveyed. The data were obtained by random sampling method.

\section{Measurements and Procedures}

\section{Personal Information Form}

A personal information form consisting of 9 questions has been prepared by the researcher to gather information about the personal characteristics of the students. It was to establish independent variables which are subject of examination of the research.

Personal information form has been developed by the researcher to find out whether the students doing sports, the year of the sport and the sports branches they do.

\section{Five Factor Personality Features Scale}

The five-factor personality scale was developed by Benet-Martinez and John [10] under the name "The Big Five Inventory" and consists of 44 items. This scale that are prepared short in terms of effective and rapid evaluations for researchers. It measures the dimensions of "neuroticism”, “extroversion”, “developmental openness”, “compatibility” and "self-discipline” among the personality traits. The factors of "neuroticism" and "extroversion" are measured by 9 items, "compatibility" and "self-discipline" by 9 items, and "development openness" by 10 items. The adaptation of the scale to the Turkish language was carried out by Sumer et al [11]. It was within the context of Turkey in a study Schmitt et al [12] on self-definition profiles and patterns of people within 56 countries. The reason for selecting the five-factor personality scale in the study is the validity and reliability of the study in the intercultural context. In the study, the five-factor personality scale showed "neuroticism", "extrovertedness", “openness to development”, “compatibility" and "self-discipline” factors as Cronbach Alpha reliability values of .79, .77, $.76, .70$ and .78 respectively Schmitt et al [12]. In some studies, with the same scale, the five factor personality dimensions were found to vary between .64 and .77 (Sumer, Lajunen and Ozkan), [13] and between .67 and .83 (Ülke) [14].

\section{Psychological Endurance Scale}

The Psychological Endurance Scale is a measure developed by Friborg et al. [15] It is tested by Basim and Çetin [16] for reliability and validity in the study "Reliability and Validity Study of Adult Psychological Endurance Scale". Then, it was adapted to Turkish.

The Psychological Endurance Scale for Adults was developed by Friborg et al. [15] It includes dimensions of 'personal power', 'structural style', 'social competence', 'family adjustment' and 'social resources'. A later study (Friborg et al., 2003) shows that the six-dimensional 
structure of the scale provides a better explanation of the psychological endurance model. In the study by Friborg et al [15], the 'personal power' dimension was divided into 'self-perception' and 'future perception' and sixdimensional structure emerged. In the scale, 'structural style' $(3,9,15,21)$ and 'future perception' $(2,8,14,20)$ are measured in four items. 'Family adjustment' $(5,11,17,23,26,32)$, 'self-perception' $(44,17,13,19,28,31)$ and 'social competence' $(4,10,16,22)$ are measured in six items, 25,29). 'Social resources' $(6,12,18,24,27,30,33)$ are measured in seven items. Printing and Çetin, [16]

The reliability and validity of the Psychological Endurance Scale

In the scale, a format is used in which the positive and negative attributes are on different sides. For responses, there are five separate quotes in order to avoid prejudiced evaluations of preferences of the items. Scoring style is set free in measuring psychological endurance high or low in schematic assessment. Confirmatory factor analysis was performed for the validity study of the scale and a total of $57 \%$ variance was reported with six factors. Internal consistency values of the structural equation model for reliability of the scale; 'Self-perception', 80, 'Future Perception', 75, 'Social Competence', 82, 'Family Compatibility', 86, 'Social Resources', 84 and 'Structural Style', 76 Basım and Çetin. [16] The Cronbach Alpha Internal consistency coefficient was calculated. It was to determine the scale's reliability at the end of the study with the teachers of the special education school. This value is determined to be 87 for all of the scale. Internal consistency coefficients of scale subscales were found to vary between 66 and 81 . Test-retest reliability was between 68 and 81 by Basım and Çetin [16]. The total score the participants can get from the scale is 165 . It was accepted that the participants with high scores had high psychological endurance and those with low scores had low psychological endurance (Basım and Çetin) [16].

Statistical Anaylysis

Data analysis was done in two steps. In the first stage, it is intended to present the situation as it is. To reach this aim, frequency and percentages from descriptive statistics are used.

In this context, the medium and standard deviations were calculated. It was to determine how personality traits and psychological endurance levels that constitute the dependent variables of the research differ according to the demographic variables of the study's independent variables. The t test was conducted. It was to determine whether the personality traits and psychological endurance levels differed according to the independent variable of the study, sport and non-sport. It was also to determine whether the present difference was significant. The t test, the $f$ test and the analysis of variance tests were used to determine whether there is a variation depending on demographic variables' situation. They were also used to determine whether this variation was significant. In order to determine the relationship between personality traits and psychological endurance, the correlation coefficient was calculated.

The obtained data were analyzed on a computer by SPSS (Statistical Package for Social Scientists for Windows Release 18.0) program, tested at a significance level of 0.05 . Other significance level was specified separately and the results were presented in tabular form for the purpose of research.

\section{Results}

When the psychological endurance levels of the participants were compared according to the sporting situation, there was no statistically significant difference $(\mathrm{t}=1,533 \mathrm{P}>0,05)$.

When the subjects' sporting situation is examined in terms of their personality traits, openness to development, extroversion and compatibility were not significantly different to the findings. It was determined that the selfdiscipline mean scores of the individuals who did and did not perform sports differ significantly $(\mathrm{t}=2,362 ; \mathrm{P}<0,05)$. Also, the self-discipline scores of the sportsmen have a higher average than those who do not.

Participants' mean scores of neuroticism, openness to development, and psychological endurance differ significantly depending on the sport year. In general, the average of the scores of neuroticism $(\mathrm{t}=3,549$; $\mathrm{P}$ $<0,05)$, openness to development $(\mathrm{t}=4,171 ; \mathrm{P}<0,05)$ and psychological endurance $(\mathrm{t}=3,184 ; \mathrm{P}<0,05)$ it seems that there is a significant difference. There is no significant difference when looking into personality's self-discipline, extroversion and compatibility sub-dimensions.

According to the branch variable, there was no statistical difference in the personality characteristics of participants who did not play sports, or did individual and team sports in terms of the difference between psychological endurance and personality traits. The psychological endurance levels differ statistically depending on the individuals not doing sports, or doing individual and team sports. The ones doing team sports

Table 1. T-test results between psychological durability score averages of individuals who do sports and who do not.

\begin{tabular}{lllll}
\hline Psychological Endurance & Sporting Situation & $\mathbf{N}$ & Average & Standard deviation \\
\hline & Yes & 216 & 3,95 &, 59 \\
& No & 149 & 3,86 &, 49 \\
& & t- test & & \\
Psychological Endurance & & t & Sd & P \\
\hline
\end{tabular}

*.05 significance level 
Pes

Table 2. T-test results between personality traits score averages of individuals who do sports and who do not.

\begin{tabular}{|c|c|c|c|c|c|}
\hline Sporting Situation & & $\mathbf{N}$ & & Average & Standard Deviation \\
\hline \multirow{2}{*}{ Openness to Self-development } & Yes & 224 & & 3,77 &, 50 \\
\hline & No & 141 & & 3,73 & ,42 \\
\hline \multirow{2}{*}{ Self-discipline } & Yes & 222 & & 3,13 & ,48 \\
\hline & No & 141 & & 3,26 & ,50 \\
\hline \multirow{2}{*}{ Extroversion } & Yes & 224 & & 3,38 & ,48 \\
\hline & No & 140 & & 3,34 & ,38 \\
\hline \multirow{2}{*}{ Compatibility } & Yes & 224 & & 3,55 &, 47 \\
\hline & No & $\begin{array}{l}141 \\
\text { t-test }\end{array}$ & & 3,56 & ,55 \\
\hline \multirow{3}{*}{$\begin{array}{l}\text { Openness to Self- } \\
\text { development } \\
\text { Self-discipline }\end{array}$} & & $\mathrm{t}$ & Sd & & $\mathrm{P}$ \\
\hline & & ,851 & 363 & & ,395 \\
\hline & & $-2,362$ & 361 & & ,019 \\
\hline Extroversion & & ,878 & 362 & & 381 \\
\hline Compatibility & &,- 158 & 363 & & ,875 \\
\hline
\end{tabular}

Table 3. F-test results regarding the difference between psychological endurance and personality characteristics according to the year of sport variance.

\begin{tabular}{lllll}
\hline Sporting Year & & N & Average & Standard Deviation \\
\hline \multirow{2}{*}{ Neuroticism } & $0-5$ year & 224 & 3,23 &, 49 \\
& $6-10$ year & 100 & 3,08 &, 48 \\
Openness to Development & $11-15$ year & 41 & 3,17 &, 44 \\
& $0-5$ year & 224 & 3,70 &, 51 \\
& 6-10 year & 100 & 3,87 &, 49 \\
Self-discipline & $0-5$ year & 41 & 3,74 &, 59 \\
& $6-10$ year & 223 & 3,62 &, 51 \\
Extroversion & $11-15$ year & 410 & 3,55 &, 40 \\
& $0-5$ year & 223 & 3,62 &, 52 \\
Compatibility & $6-10$ year & 100 & 3,35 &, 59 \\
& $11-15$ year & 41 & 3,37 &, 52 \\
Psychological Endurance & 224 & 3,39 &, 47 \\
& $0-5$ year & 100 & 3,55 &, 51 \\
\hline
\end{tabular}

Table 4. F-test results regarding the difference between psychological endurance and personality characteristics according to the year of not doing sports variable.

\begin{tabular}{|c|c|c|c|c|c|c|}
\hline Sporting Year & & Sum of Squares & df & $\begin{array}{l}\text { Averages of } \\
\text { Squares }\end{array}$ & $\mathbf{F}$ & Sig. \\
\hline \multirow{3}{*}{ Neuroticism } & Between Groups & 1,675 & 2 & ,837 & 3,549 & ,030 \\
\hline & Inside Groups & 85,426 & 362 & ,236 & & \\
\hline & Total & 87,100 & 364 & & & \\
\hline \multirow{3}{*}{$\begin{array}{l}\text { Openness to } \\
\text { Development }\end{array}$} & Between Groups & 1,793 & 2 & ,897 & 4,171 & ,016 \\
\hline & Inside Groups & 77,807 & 362 & 215 & & \\
\hline & Total & 79,600 & 364 & & & \\
\hline \multirow{4}{*}{ Self-discipline } & Between Groups & ,404 & 2 & 202 & ,733 & 481 \\
\hline & Inside Groups & 99,436 & 361 & ,275 & & \\
\hline & Total & 99,839 & 363 & & & \\
\hline & Between Groups & ,078 & 2 & ,039 & ,194 & ,824 \\
\hline \multirow[t]{2}{*}{ Extroversion } & Inside Groups & 72,351 & 361 & 200 & & \\
\hline & Total & 72,429 & 363 & & & \\
\hline \multirow{3}{*}{ Compatibility } & Between Groups &, 075 & 2 & ,037 & 150 & ,861 \\
\hline & Inside Groups & 90,514 & 362 & ,250 & & \\
\hline & Total & 90,588 & 364 & & & \\
\hline \multirow{3}{*}{$\begin{array}{l}\text { Psychological } \\
\text { Endurance }\end{array}$} & Between Groups & 1,956 & 2 & 978 & 3,184 & 043 \\
\hline & Inside Groups & 111,162 & 362 & ,307 & & \\
\hline & Total & 113,118 & 364 & & & \\
\hline
\end{tabular}

*.05 significance level 
Table 5. Findings related to the difference between psychological endurance and personality characteristics according to sport branch variables.

\begin{tabular}{|c|c|c|c|c|c|c|}
\hline \multicolumn{4}{|l|}{ Sports Branch } & \multirow{2}{*}{$\begin{array}{l}\mathbf{N} \\
141\end{array}$} & \multirow{2}{*}{$\begin{array}{l}\text { Average } \\
3,24\end{array}$} & \multirow{2}{*}{$\begin{array}{l}\text { Standard } \\
\text { Deviation } \\
49\end{array}$} \\
\hline \multirow{5}{*}{ Neuroticism } & \multicolumn{3}{|l|}{ Non-sporting } & & & \\
\hline & \multicolumn{3}{|l|}{ Team sports } & 113 & 3,11 & ,46 \\
\hline & \multicolumn{3}{|l|}{ Individual sports } & 111 & 3,18 & ,51 \\
\hline & \multicolumn{3}{|l|}{ Total } & 365 & 3,18 & ,49 \\
\hline & \multicolumn{3}{|l|}{ Non-sporting } & 141 & 3,73 & ,41 \\
\hline \multirow{4}{*}{$\begin{array}{l}\text { Openness to } \\
\text { Development }\end{array}$} & \multicolumn{3}{|l|}{ Team sports } & 113 & 3,74 & ,53 \\
\hline & \multicolumn{3}{|l|}{ Individual sports } & 111 & 3,79 & ,46 \\
\hline & \multicolumn{3}{|l|}{ Total } & 365 & 3,75 & ,47 \\
\hline & \multicolumn{3}{|l|}{ Non-sporting } & 140 & 3,60 &, 54 \\
\hline \multirow{4}{*}{ Self-discipline } & \multicolumn{3}{|l|}{ Team sports } & 113 & 3,59 & ,50 \\
\hline & \multicolumn{3}{|l|}{ Individual sports } & 111 & 3,62 & ,53 \\
\hline & \multicolumn{3}{|l|}{ Total } & 364 & 3,60 & ,52 \\
\hline & \multicolumn{3}{|l|}{ Non-sporting } & 140 & 3,34 & 37 \\
\hline \multirow{4}{*}{ Extroversion } & \multicolumn{3}{|l|}{ Team sports } & 113 & 3,42 & ,49 \\
\hline & \multicolumn{3}{|l|}{ Individual sports } & 111 & 3,33 & ,49 \\
\hline & \multicolumn{3}{|l|}{ Total } & 364 & 3,36 & ,45 \\
\hline & Non-sporting & & & 141 & 3,56 & ,54 \\
\hline & Team sports & & & 113 & 3,57 & ,52 \\
\hline Compatibility & Individual sports & & & 111 & 3,55 & ,43 \\
\hline & Total & & & 365 & 3,56 & ,50 \\
\hline & Non-sporting & & & 141 & 3,88 & ,46 \\
\hline Psychological & Team sports & & & 113 & 4,03 & 63 \\
\hline Endurance & Individual sports & & & 111 & 3,85 & ,58 \\
\hline & Total & & & 365 & 3,92 & ,56 \\
\hline & & KT & $\mathrm{Sd}$ & KO & $\mathrm{F}$ & P. \\
\hline & Between Groups & 1,062 & 2 & ,531 & 2,234 & 109 \\
\hline Neuroticism & Inside Groups & 86,038 & 362 & ,238 & & \\
\hline & Total & 87,100 & 364 & & & \\
\hline & Between Groups & 294 & 2 & 147 & 671 & ,512 \\
\hline $\begin{array}{l}\text { Openness to } \\
\text { Develonment }\end{array}$ & Inside Groups & 79,306 & 362 & 219 & & \\
\hline & Total & 79,600 & 364 & & & \\
\hline & Between Groups & ,057 & 2 & ,028 & 103 & 902 \\
\hline Self-discipline & Inside Groups & 99,783 & 361 & ,276 & & \\
\hline & Total & 99,839 & 363 & & & \\
\hline & Between Groups & ,656 & 2 & ,328 & 1,649 & 194 \\
\hline Extroversion & Inside Groups & 71,773 & 361 & 199 & & \\
\hline & Total & 72,429 & 363 & & & \\
\hline & Between Groups & ,030 & 2 & ,015 & ,061 & 941 \\
\hline Compatibility & Inside Groups & 90,558 & 362 & ,250 & & \\
\hline & Total & 90,588 & 364 & & & \\
\hline & Between Groups & 2,188 & 2 & 1,094 & 3,570 & 029 \\
\hline $\begin{array}{l}\text { Psychological } \\
\text { Pndurance }\end{array}$ & Inside Groups & 110,930 & 362 & ,306 & & \\
\hline Endurance & Total & 113,118 & 364 & & & \\
\hline
\end{tabular}

*.05 significance level

have higher average than the ones doing individual sports. The ones doing individual sports have higher $(\mathrm{t}=3,570$; $\mathrm{P}$ $<0,05)$ average than the ones not doing sports.

\section{Discussion}

The study that was conducted to examine the psychological endurance and personality traits of the individuals who do and do not perform sports according to various variables had these results. The results of psychological endurance and sub-dimensions of the students are considered relating the personal characteristics of students. It is seen that there is no significant difference 
in terms of psychological endurance between sporting and non-sporting individuals. In such a conclusion, it can be considered that the psychological process in which the individual is involved is influential. Indeed, there are many studies that overlap with the results we have arrived. When Bulbul (2015) was researching with basketball and tennis players, the psychological endurance did not show any significance for the athlete. In addition, Sezgin [17], Sönmezer [18] and Tümlü and Recepoğlu [19] have found that psychological endurance is not significant in terms of individuals. Even though the teachers are in different branches when they study the teachers and academicians. The results of the students' personalities and sub-dimensions are taken into consideration. It was in accordance with the personal characteristics of the students of the sports science faculty and the education faculty. There was a meaningful difference in terms of the Self Discipline Sub-dimension. However, there was no significant difference in terms of the Five Factor Personality Scale's Openness to Development, Extroversion and Compatibility subscales. Looking at the average scores of openness to development, extroversion and compatibility subscales, the average score of the sportsmen are higher than those of the non-sportsmen. However, it is seen that the average scores of selfdiscipline sub-dimension for non-sporting are higher than those who do sports. Some parallel works are as follows. Cameron et al [20] found that there was some consensus on the positions of players in different positions according to the results of their research. The research had 578 male ice hockey players (163 defenders, 305 attackers and 110 scorers) to determine the personality characteristics of the ice hockey athletes according to the position they played. It has been observed that offensive players are more extrovert, incomprehensible, without self-discipline and experiment-oriented than defenders and scorers. After examining the personality traits and psychological endurance levels of the students in terms of the variation of sporting years, there was no significant difference in terms of Self Discipline, Compatibility and Extroversion. However, it was found that there was a significant difference in terms of Psychological Endurance (It is observed that those who play sports between 6-10 years and 11-15 years have higher Psychological Endurance levels than those who play sports between 0-5 years), Openness to Development (It is seen that those who play sports between 6-10 years and 11-15 years have a higher level of openness to development than those who play sports between $0-5$ years) and Neuroticism Sub-dimension (It is observed that those who play 0-5 years have higher levels of neuroticism than those who play between 6-10 years and 11-15 years). According to the results obtained, in terms of the increase in sporting year, it was observed that there is an increase in openness to development and the psychological endurance levels. Whereas, the increase in the level of neuroticism was observed in those with less sports years. Kurtipek [21] had a study about "The personality structures of the high school students who are training in sports and the comparison with the students in other high schools”. It shows that the results are parallel to our study in terms of scale point averages considering the year of sporting. The personality traits and the psychological endurance levels of the students from the perspective of branch variation were examined. The results of psychological endurance and personality levels and scale sub-dimensions of students are considered. Examining the personality traits and psychological endurance levels from the point of the sport branch variables, no significant difference was observed in terms of Openness to Development, Self-Discipline, Compatibility, Extroversion and Neuroticism. There was a significant difference in terms of Psychological Endurance. The psychological endurance levels of those who do not play sports are lower than those who do any individual sports or team sports. In short, it can be said that doing sports affects psychological endurance positively. Our findings of the study are parallel to the study of Salar, Hekim and Tokgöz [22]. If sportsmen who do team and individual sports in the age group of 15-18 years are regularly doing sports for 3-4 days, they feel emotionally good. In the same study, the levels of emotional well-being of the individuals who do both team and individual sports are similar.

\section{Conclusion}

It is seen that psychological endurance levels of participants are not statistically different when compared to sporting situations. Psychological endurance levels of sportsmen have a higher average than who does not do sports. The participants' sporting situation is compared in terms of their personality characteristics. There was no statistically significant difference in the openness to development, extroversion and compatibility characteristics. It has been determined that the selfdiscipline average scores of the individuals who do and do not sports differ significantly from the statistically significant level. The self-discipline scores of the sportsmen have a higher average than those who do not. According to the branch variable, there was no statistically difference in the personality characteristics in terms of the difference between psychological endurance and personality traits. Participants were who did not play sports and who did individual and team sports. It is observed that psychological endurance levels differ statistically depending on the individuals not doing sports, doing individual and team sports. Individuals who perform team sports have higher average than individuals who do individual sports. Individuals who do sports have higher than those who do not. According to the sport year variable, the average scores of neuroticism, openness to development and psychological endurance differ significantly depending on the sport year. As the duration of sports in general increases, the average scores of neuroticism, openness to development and psychological endurance increase.

\section{Conflict of interests}

The authors declare that there is no conflict of interests. 


\section{References}

1. Terzi S. The Relation Between Self-Reliance and Internal Protective Factors in University Students. Hacettepe University Journal of Education, 2008; (35): 297-306.

2. Masten AS. Ordinary Magic: Resilience Process İn Development. American Psychologist, 2001;56(3): 227-238.

3. Herrenkohl EC, Herrenkohl RC, Egolf BP. The Psychosocial Consequences of Living Environment İnstability On Maltreated Children. American Journal of Orthopsychiatry, 2003;73(4): 367-380.

4. Masten AS, Coatsworth JD. The Development of Competence İn Favorable and Unfavorable Environments: Lessons from Research on Successful Children. American Psychologist, 1998;53(2): 205-210.

5. Kobasa SC. Stressful Life Events, Personality, And Health: An İnquiry İnto Hardiness. Journal of Personality and Social Psychology, 1979;37(1): 1-13.

6. Luthar SS, Cicchetti D, Becker B. The Construct of Resilience: A Critical Evaluation and Guidelines for Future Work. Child Development, 2000;71(3):543-562.

7. Burger JM. Personality: The Psychology of Science on Human Nature. Istanbul: Kaknüs Publications; 2006

8. Köknnel Ö. Personality through Anxiety to Happiness. Istanbul: Golden Book Publishing House; 1982.

9. Feist J. Theories of Personality. New York: Mc Neese State University; 1990.

10.Benet-Martinez V, John OP. Los Cinco Grandes Across Cultures and Ethnic Groups: Multitrait-Multimethod Analyses of The Big Five in Spanish and English. Journal of Personality and Social Psychology, 1998;75(3): 722-283.

11.Sümer N, Lajunen T, Özkan T. Big Five Personality Traits as The Distal Predictors of Road Accident İnvolvement. In G. Underwood (Ed.), Traffic and Transport Psychology. Oxford: Elsevier Ltd; 2005.

12.Schmitt DP, Allik J, Mccrae RR, Benet-Martinez V. The Geographic Distribution of Big Five Personality Traits: Patterns and Profiles of Human Self-Description Across 56 Nations. Journal of Cross-Cultural Psychology, 2007;38(2): 173-212.
13.Sümer N, Lajunen T, Özkan T. Big Five Personality Traits as The Distal Predictors of Road Accident İnvolvement. In: G. Underwood (Ed.), Traffic and Transport Psychology. Oxford: Elsevier Ltd; 2005.

14.Ulke HE. Investigation of the Role of Personality and Justice on Social Resilience. Unpublished master's thesis, Ondokuz Mayıs University: Institute of Social Sciences; 2006.

15.Friborg O, Hjemdal O, Rosenvinge JH, Martinusse M. A New Rating Scale For Adult Resilience: What Are The Central Protective Resources Behind Healthy Adjustment?. International Journal Methods Psychiatry Research, 2003;11(12): 65-76.

16.Basım HN, Cetin F. Reliability and Validity Study of Adult Psychological Endurance Scale. Turkish Journal of Psychiatry, 2011; 22 (2): 104-114.

17.Sezgin F. Investigation of Psychological Endurance Levels of Primary School Teachers. Kastamonu Education Journal, 2012;20 (2): 489-502.

18.Sönmezer B. Investigation of Teachers' Burnout and Psychological Endurance Levels. Master Thesis. Erciyes University: Institute of Educational Sciences; 2015.

19.Tümlü GÜ, Recepoğlu E. The Relationship Between Psychological Endurance and Life Satisfaction of University Academic Staff. Journal of Higher Education and Science, 2013; 3 (3): 205-213.

20.Cameron JE, Cameron JM, Dithurbide Lalonde RN. Personality Traits and Stereotypes Associated with Ice Hockey Positions. Journal of Sport Behavior, 2006;35(2): 109-124.

21.Kurtipek S. Examination of the Personality Patterns of the Students in the High Schools that Provide Sports Education and Comparison with Other High School Students. Unpublished master's thesis. Gazi University: Institute of Health Sciences; 2003.

22.Salar B, Hekim M, Tokgoz M. To Compare Emotional State Of İndividuals Making Team And İndividual Sport 15-18 Age Group. Mehmet Akif Ersoy University Journal of Social Sciences Institute, 2012; 4(6):123-135. 


\section{Information about the authors:}

Şar Nuriye Şeyma (Corresponding author); Research assistant; http://orcid.org/0000-0003-0460-2263; nseymasar@gmail.com; High School of Physical Education and Sports, Mustafa Kemal Univercity; serinyol campüs Hatay/Antakya, Turkey.

Soyer Fikret; Assoc.Prof.Dr; http://orcid.org/0000-0002-8528-3622; fikretsoyer@sakarya.edu.tr; Physical Education and Sports Science Faculty, Sakarya University; Esentepe campüs Sakarya/Adapazarı,Turkey.

Koç Mustafa; Assoc.Prof.Dr.; http://orcid.org/0000-0002-8644-4109; mkoc@sakarya.edu.tr; Education Faculty, Psychological Counseling and Guidance Service, Sakarya University; Hendek campüs, Sakarya/Hendek ,Turkey.

Cite this article as: Şar Nuriye Şeyma, Soyer Fikret, Koç Mustafa. An analysis of psychological endurance and personality traits of individuals doing sports and not doing sports by various variables. Physical education of students, 2018;22(2):91-98. doi:10.15561/20755279.2018.0206

The electronic version of this article is the complete one and can be found online at: http://www.sportedu.org.ua/index.php/PES/issue/archive

This is an Open Access article distributed under the terms of the Creative Commons Attribution License, which permits unrestricted use, distribution, and reproduction in any medium, provided the original work is properly cited (http://creativecommons.org/licenses/by/4.0/deed.en).

Received: 05.01.2018

Accepted: 27.01.2018; Published: 27.04.2018 